\title{
Various medicinal plants traded in the village market of Karangwangi Village, Southern Cianjur, West Java, Indonesia
}

\author{
BUDIAWATI S. ISKANDAR ${ }^{1}$, JOHAN ISKANDAR ${ }^{2}$, RUHYAT PARTASASMITA ${ }^{2, \boldsymbol{v}}$, BUDI IRAWAN ${ }^{2}$ \\ ${ }^{1}$ Department of Anthropology, Faculty of Social and Political Sciences, Universitas Padjadjaran. Jl. Raya Bandung-Sumedang Km 21 Jatinangor, \\ Sumedang 45363, West Java, Indonesia \\ ${ }^{2}$ Department of Biology, Faculty of Mathematics and Natural Sciences, Universitas Padjajaran. J1. Raya Bandung-Sumedang Km 21, Jatinangor, \\ Sumedang 45363, West Java, Indonesia. Tel.: +62- 22-7797712. •email: ruhyat.partasasmita@unpad.ac.id, rp2010rikkyo@gmail.com
}

Manuscript received: 1 June 2020. Revision accepted: 31 August 2020.

\begin{abstract}
Iskandar BS, Iskandar J, Partasasmita R, Irawan B. 2020. Various medicinal plants traded in the village market of Karangwangi Village, Southern Cianjur, West Java, Indonesia. Biodiversitas 21: 4440-4456. In the past traditional village, the market was predominantly found in many villages of West Java. The village markets were usually held once a week. The traders of the village market mainly were from both local villagers or people coming from the nearby towns. Nowadays, the village markets of West Java have dramatically decreased because of the existence of permanent shops (toko) and minimarkets in the rural areas that operate daily. However, in some villages, such as Karangwangi Village, Cidaun Sub-district, Southern Cianjur, West Java, village markets still exist. In the Karangwangi Village market, various plants are commonly traded, such as staple foods, vegetables, fruits, spices, and traditional medicines. The purpose of this study was to discuss the various traditional medicinal plants traded in the village market, some diseases treated by the various herbal plants, various plant parts used for traditional medicines, and original medicinal plants in the village markets of Karangwangi Village. The research method used was qualitative, with data collection carried out by observation, by recording various traditional medicinal plants traded in the village market, and by interviewing informants regarding the use of each medicinal plant species for the treatment of diseases and the origin of plant traded in village markets. The results of the study showed that 35 species representing 23 families of the medicinal plant were documented to be traded in the traditional village markets of Karangwangi Village. These plants are predominantly used to treat 20 kinds of diseases and other disturbance conditions, namely anemia, cough, fever, diabetes, wound, gastritis, malaria, bruised, supplement, toothache, kidney disease, mouth sores, stomachache, high blood pressure, postpartum healing, low back pain, urinary disease, rich breastfeeding produce, dermatitis, and gastroenteritis. Plant parts used for medicinal ingredients in the form of leaf, fruit, bulb, rhizome, root, seed, and shoot. Some medicinal plants have been known to have dual function, such as medicine and vegetables (13 species (36.36\%)), medicines and herbs (12 species (34.28\%)), medicines and spices (10 species $(28.57 \%)$ ), medicines and fruits $(8$ species $(22.85 \%))$, medicines and staple food $(3$ species $(8.57 \%))$, medicines, vegetables and spices (1 species $(2.85 \%)$ ), and medicine and to betel ingredient (1 species $(3.03 \%)$ ). Most of the origin of medicinal plants traded in the village market is from the village with 23 species (65.71\%), from cities with 9 species (25.71\%), and from both villages and cities with 3 species $(8.57 \%)$. On this basis, it can be concluded that the traditional village market has played an important role not only for social-economic interests but also for biodiversity conservation, including biological ingredients for traditional medicines of the rural communities.
\end{abstract}

Keywords: Diseases, medicinal plants, village market, West Java

\section{INTRODUCTION}

The market is the place where a transaction between sellers and buyers is undertaken (Supangkat 2012; Septiari 2016). The market in Indonesia may be divided into two types, namely modern markets and traditional markets (Septiari 2016). The modern markets are generally described by the physical condition of buildings that are more sophisticated with tools that rely on high technology. In addition, in the modern market, goods are sold at 'fixed price'. There is no possibility of bargaining so that face-toface and active social relations for communication between traders and buyers may not happen in modern markets. On the other hand, the traditional markets are generally in simple physical condition, buying and selling activities are realized based on the bargaining principle that the 'sliding price' system is possible to happen. In addition to this bargaining, social relations are activated (Supangkat 2012;
Fadlilah and Wijana 2018).

Moreover, traditional markets may be divided into three categories. First is traditional markets in regency and municipal cities, as well as provincial cities, which are open every day, especially early morning until 10: 00 am to 11: 00 am (Supangkat 2012; Iskandar et al. 2018). Second is traditional markets which take place in several places on the roadside or field in cities. This market model is almost the same as the traditional market type, but the place of selling is less permanent and opens once a week (Syarifuddin 2018). The third is traditional markets in the villages which are open once a week, in the morning until 10: 00 to 11: $00 \mathrm{am}$.

Based on ecological history or environmental history, the existence of traditional markets in the village, in the form of weekly markets in Java, such as Central Java and in West Java has been recorded for a very long time (Nastiti 2003; Iskandar and Iskandar 2020). Similarly, 
traditional markets in the city have also been built for a long time. For instance, the Pringharjo traditional market in the city of Yogyakarta was built in 1758 (Herliana 2015). Traditional markets both in rural and urban areas have important functions not only for socio-economic functions for the community, but also for historical, socio-cultural functions for the community, and the media to trade various agricultural productions of farmers, such as fresh fruits, fresh vegetables, fishes, spices, nuts, medicinal plants, and pet / live birds (Suryadarma et al. 2010; Sidabutar et al. 2012; Irwanta et al. 2015; Silalahi et al. 2015; Iskandar et al. 2018; 2020; Alfian et al. 2020).

However, in the last few decades, traditional markets in the city have been pushed by many modern markets, such as supermarkets (Suryadarma et al. 2010; Susilowati 2014; Septiari 2016; Nelwan et al. 2017).

Like traditional urban markets, the traditional village markets have also been dramatically influenced by the rapid development of permanent village shops and minimarkets. As a result, some village traditional markets, including village markets in West Java have disappeared (Iskandar and Iskandar 2020). The extinction of village markets in many rural villages can cause loss of many socio-economic and ecological functions. In terms of ecological functions, for example, the disappearing of traditional village markets may cause various local plant diversities of rural areas traded in rural areas to be reduced. On the other hand, various agricultural productions of farmers have many obstacles, such as product quality and competition that leads to monopoly or oligopoly system. As a result, various farmers' plant production cannot freely enter the urban modern market (Nahraeni et al. 2018). This causes less encouragement to farmers to cultivate and conserve plant biodiversity in their villages. Besides, residents' knowledge of the diversity of local plant species and their cultivation systems is also to be eroded. Because of the local knowledge is usually passed on orally from generation to generation using mother language and based on direct field experiences (Berkes 2008; Iskandar 2018). Mother language and oral tradition are essential links in the survival of traditional and serve as an integrational thread (Edwards 2010). The protecting and promoting small scale framers, including their agricultural production to trade in the village market, may support the protection and conservation of biodiversity of agroecosystem species and the food security and village people's health conditions. Because biodiversity, local knowledge, the cultural practice of the agroecosystem management, and market development are closely interlinked. Within traditional agroecosystem, practice that is strongly embedded with local knowledge and culture in the rural ecosystem may promote biodiversity conservation and enhance the sustainability of rural people's livelihood (Shiva 2016).

Although in many rural areas in West Java many village markets have been lost, some village markets have still been found in Cianjur District. One village in Cianjur District which still has a traditional market is Karangwangi Village, Cidaun Sub-district, Cianjur District, West Java (Iskandar and Iskandar 2020). Some studies on various plant species traded in traditional urban markets have mainly carried out (Sidabutar et al. 2012; Irwanta et al. 2015; Susanti 2015; Iskandar et al. 2018). However, studies on various plants traded in village markets have been rarely undertaken. Therefore, studies on various plant products traded, particularly medicinal plants traded in village markets are very interesting to undertake.

This article is to elucidate the various traditional medicinal plants traded in the village market, the diseases treated by the various herbal plants, various plant parts used for traditional medicines, and origin of medicinal plants traded in the village markets of Karangwangi Village, Southern Cianjur, Java West, Indonesia

\section{MATERIALS AND METHODS}

\section{Study area}

This research was undertaken in two main locations. The first location was Karangwangi Village, Cidaun Subdistrict, Cianjur District, West Java, Indonesia with the aim to study local knowledge of village people on various diseases that are commonly treated by various medicinal plants (Figure 1). The second location was the traditional market village of Puncak Bayuning and Jayanti, Karangwangi Village, Cidaun Sub-district, Cianjur, West Java with the aim to study traditional practices of village market and to document various medicinal plants usually traded in village markets.

Karangwangi Village is located in altitude approximately $200 \mathrm{~m}$ and $275 \mathrm{~m}$ above sea level. This village has two seasons, namely wet and dry season. Karangwangi has rainfall about 3,500 $\mathrm{mm} /$ year, with air temperature approximately $35^{\circ}$ Celsius. Therefore, it can be considered to be appropriate for supporting the agricultural activities of village people.

Access to get to Karangwangi Village from the city of Bandung as the capital city of West Java can be done through several routes, including bypassing the CiwideyRancabali-Naringgul-Cidaun-Karangwangi lines. This route takes about 3 hours to drive through a forest area that is still quiet and with lush vegetation of the village ecosystem with a winding and steep road. The second route is through Garut-Bungbulang-Rancabuaya-Karangwangi with 5 hours of travelling. The condition of the road is good and has been asphalted and is a southern coastline so that it presents the beauty of the southern beach of West Java.

The third route is the route taken through the BandungPangalengan-Cisewu-Caringin-Karangwangi Village. If from Pangalengan, this route can be taken in about 2 hours 45 minutes, with good road conditions but winding and narrow. In addition, we can also use the fourth route from the direction of Cianjur city. For this route, it is through several sub-districts, namely Cilaku-Cibeber-CampakaPagelaran-Tanggeung-Cibinong-Sindangbarang-CidaunKarangwangi Village. The distance from Cianjur district city to Karangwangi Village can be taken a little longer with a time of more than 5 hours. 

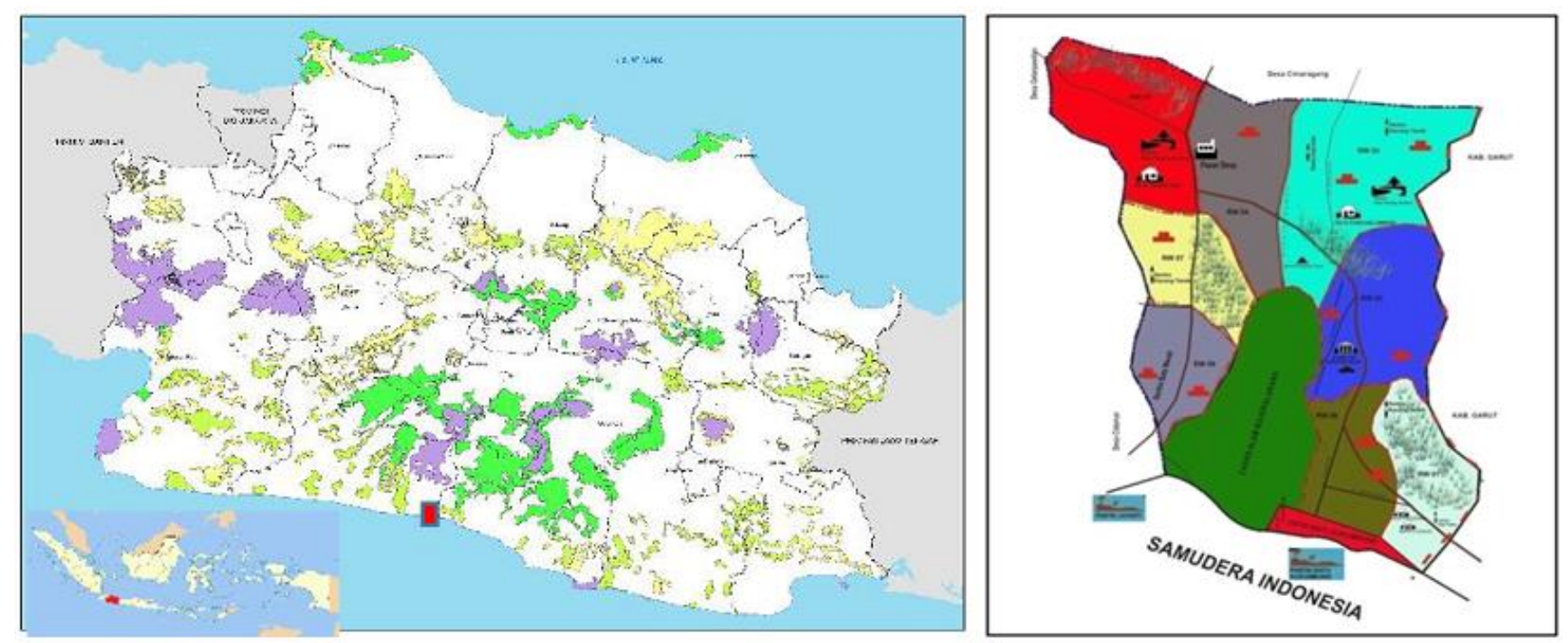

Figure 1. Map of Karangwangi Village, Cidaun Sub-district, Cianjur District, West Java, Indonesia (Partasasmita et al. 2016)

Karangwangi Village has five main agroecosystem types, namely homegarden (pekarangan or buruan), garden (kebon), mixed-garden (kebon tatangkalan, kebon kai or talun), swidden cultivation (huma), and wet-rice field system (sawah) (Iskandar and Iskandar 2016) (Figure 2). Three types of agroecosystems of Karangwangi Village, namely homegarden, mixed gardens, and swidden cultivation, can be categorized as traditional agroforestry systems. Homegarden may be defined as the land located in the surrounding house that is usually planted by mixed annual and perennial crops; mixed-garden is the land located outside of the house that is planted by mix perennial crops; while garden is also located outside a house that is predominantly planted by annual crops. Homegarden, mixed-garden, and swidden cultivation can be classified as the traditional agroforestry system. The traditional agroforestry system may be defined as a landuse system that resembles a forest in structure and combines the natural functions of a forest with those for fulfilling socio-economic needs of the rural people (Soemarwoto and Soemarwoto 1984). Some ecological functions of the traditional agroforestry systems are producing oxygen $\left(\mathrm{O}_{2}\right)$ and absorbing $\mathrm{CO}_{2}$ as one of the greenhouse gases causing of global warning, maintaining soil fertility, protecting soil from erosion, maintaining a watershed hydrological system balance, becoming a wildlife habitat such as birds and insects, and performing germplasm conservation (Iskandar 2017). Besides that, with the presence of a large number of perennial and annual crops in traditional agroforestry, it has provided some socio-economic and cultural benefits for village people, including producing additional sources of staple food, fruits, spices, vegetables, traditional ceremonial materials, and traditional medicinal materials.

Karangwangi Village consists of 3 hamlets namely Lebakwangi, Mekarwangi, and Puncak Jaya. The population of Karangwangi Village in 2018 was 6,618 people, representing 2,147 households. The predominant land is used for agricultural land. Therefore, most of the Karangwangi involved in the agricultural sector, as farmers and farm laborers. Additionally, the livelihoods of other people are recoded as fishermen, traders, civil servants, and private employees.

\section{Data collection}

This study was undertaken in two stages. The first stage was to study local knowledge of village people on various diseases that were traditionally treated by using various medicinal plants employed between April and May 2016. The second stage was to study various medicinal plants that were commonly traded in traditional village markets carried out in 7-24 May 2016. The qualitative method was employed in both stages, while some field techniques including observation, inventory of plant traded in village markets, and semi-structure interviews with informants were done (cf. Martin 1996; Alburquet et al. 2014; Ferreira et al. 2014; Iskandar 2018).

As a first approach to any ethnobiological research consent seeking and ethical consideration were carefully considered. Thus, following the requirement of the International Society for Ethnobiology (ISE) code of ethics, we were careful to ensure that the rights of individuals were not infringed upon. We ensure that no informants were forced into participating in the research. We firstly asked formal authorization to research by submitting the permission letter to the village leader of Karangwangi. In addition, before interviewing with informants we always asked them for obtaining permission and oral consent instead of written that was culturally acceptable in the study communities and so was utilized (Alburquerque et al. 2014a). 


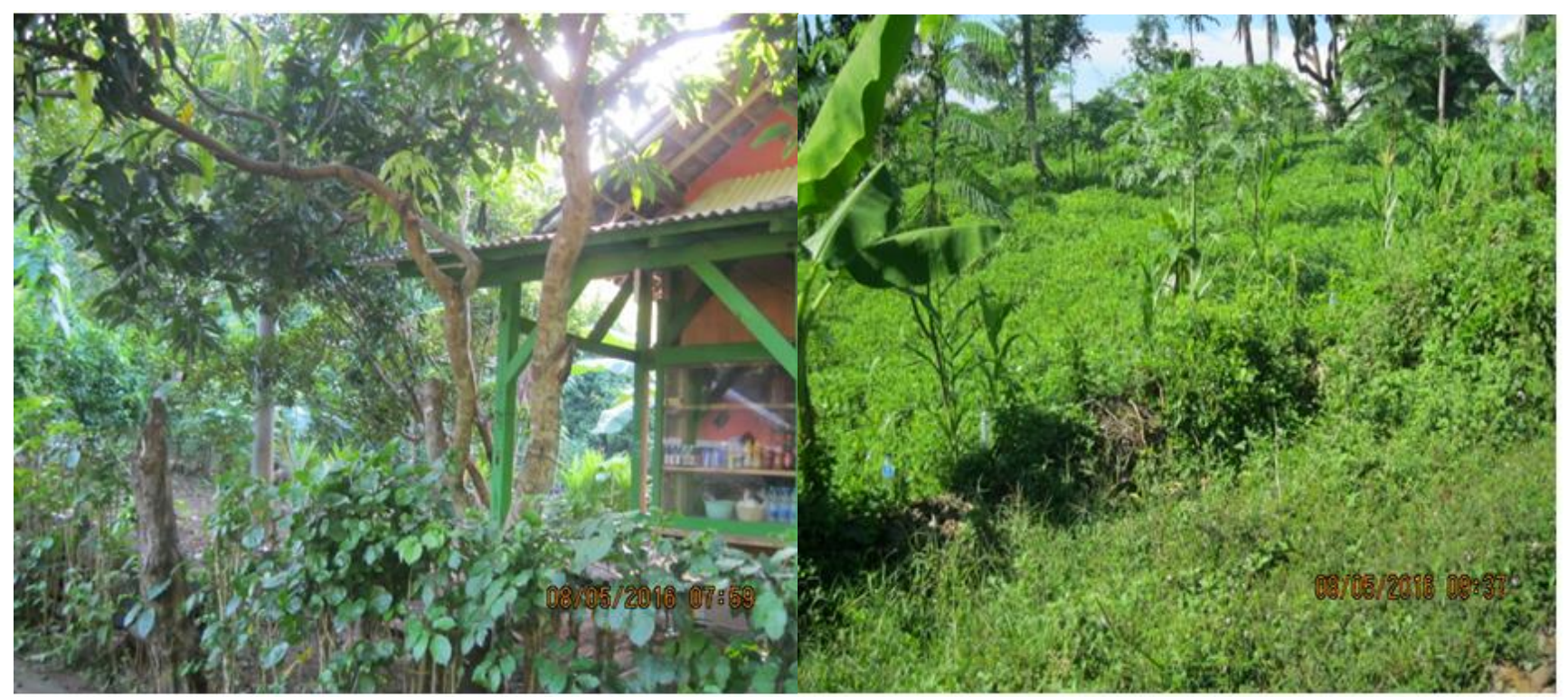

Figure 2. Homegarden (left) and mixed-garden system (right) that is planted by annual and perennial crops, including traditional medicine crops

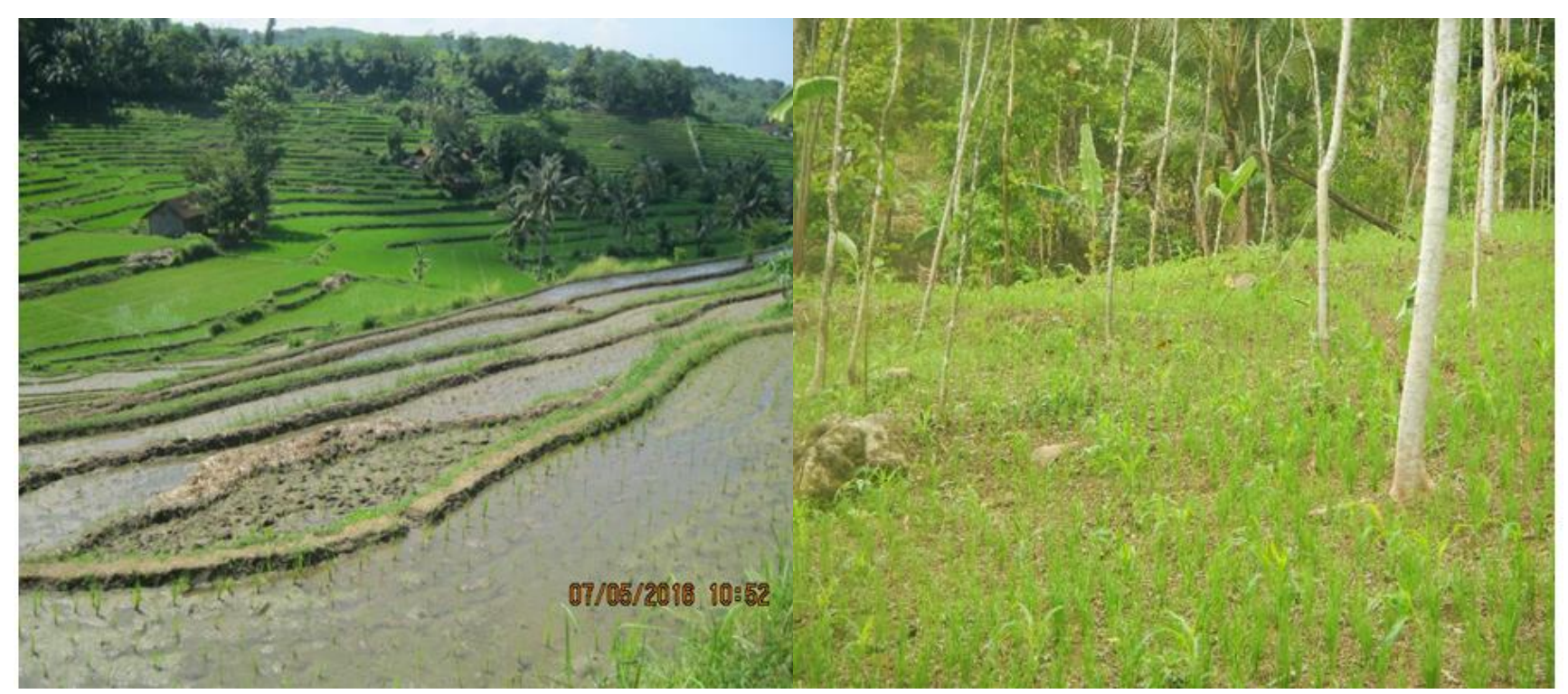

Figure 3. Wet-rice (left) and swidden cultivation system (right) is predominantly planted by rice and other annual crops, including traditional medicine plants

For the first stage of the study, the observation and semi-structured interviews were employed. The observation was undertaken to comprehend local village environment conditions, including agroecosystem types, namely huma, homegarden, garden, mixed garden, and rice field, and forest ecosystem. In addition, the observation was carried out to observe village people's activities in the use of various plants for treating various diseases. While the semi-structured interview was undertaken with competent informants, including hamlet leaders, village chiefs, male shamans (dukun laki-laki), female shamans (dukun perempuan), male elder farmers, female elder fishermen that were purposively selected. To identify plant species that have not been directly identified in the field, some plant herbariums were made and plant identification was undertaken in the plant taxonomy laboratory at the Department of Biology, Padjadjaran University.

The second stage, namely, the observation, inventory of plant traded in the village markets, and semi-structure interviews, was performed. The observation was applied to observe the village market condition and various activities of village market traders during regular hours of trading in the village market. Interviews with informants, including the medicinal plant traders, vegetable, spice, and fruit traders (cf. Cunningham 2001; Albuquerque et al. 2014b, c; Iskandar 2018). In addition, the interview was undertaken 
with consumers, village leaders, farmers, and fishermen to know well various aspects of village traditional markets. To record various medicinal plants traded in village markets, special plant inventory was done by visiting the market early in the morning several times in a different month. Information of all medicinal plants traded in the village markets was recorded, including the local name, the main function for using traditional medicine purposes, and the main sources of those medical plants. Identification of the plant species was done by using specific literature, taking photographs, and collecting specimens of unidentified species and properly labeling it for the voucher specimen. To record and identify species of medicinal plants used several identification books on plant species written by Heyne (1987), Dirjen POM (1989), and Valkenburg and Bunyapraphatsan (1999)

\section{Data analysis}

Data analysis was conducted by crosschecking, summarizing, synthesizing, and building up a narrative account (Newing et al. 2011; Albuquerque et al. 2014). Crosschecking was done to validate data that were obtained from various techniques, including observation, plant species survey, and a semi-structured interview with informants. This crosschecking data was summarized and synthesized and narrated in a descriptive analysis. Specifically, the results of an inventory of the species of plants traded are analyzed by identifying the scientific names of species of medicinal plants, then analyzing their functions for the treatment of various diseases and functions other than medicine functions, such as vegetables, spices, and fruits; part of the plant used for medicinal materials and analyzed the origin of the species of medicinal plants traded in the village market. The species of medicinal plants traded in the Karangwangi Village market were also analyzed for their use as medicinal ingredients based on the Medical Herbal Index in Indonesia literature from Kasahara and Hemni (1995).

\section{RESULTS AND DISCUSSION}

\section{Village market}

On the basis of ecological history, before the 1980s the village markets have predominantly found in many villages of West Java (Iskandar and Iskandar 2020). Because of the increased population and intensive penetration of the market economic system to village areas, the village markets are decreasing. For example, in 2012 the number of village markets in the Cidaun Sub-district was 13, while the number of mini markets and small shops was 1,013. Four years later, in 2016, the number of village markets in the Cidaun Sub-district reduced and was only 7 , conversely, the number of mini-market increased, and was 1,943 (Statistical data of Cidaun 2017). Today, at least 7 village markets (pasar desa) in Cidaun Sub-district have continuously operated (Table 1). Each village market is weekly operated. For instance, the village market of Puncak Bayuning and Lapang Jayanti are operated on Monday and Thursday, respectively.

As can be seen from Table 1, the village market mainly opens only once a week. The traders who sell in the village markets are a mixture of local village traders and city traders. However, consumers of these village markets are mainly local villagers. Traders from the city selling in the village markets are usually non-permanent traders. The reason is that almost every day there will be other village markets in other village remote areas. Therefore, traders from urban usually move from one village to another village to sell their goods.

The village market is usually placed in an open place, such as a field or village roadside. Most buildings in the village market are not permanent but are merely places to put on a plastic mat in the field or the village roadside. Various commodities are usually put on a stretch of the plastic mat on the ground or on wooden or bamboo tables. Both wooden tables or bamboo tables can be easily moved into the appropriate safe place of the village market.

The village markets usually open early in the morning after dawn until approximately eleven o'clock, before midday (duhur). Therefore, the traders from the city usually have been in the village market the day before. They usually keep their commodities stacked in each stall. They bring their commodities from the city to village markets by pickups (mobil buntung) or motorbikes. However, local traders from the local village, usually, come to the village market in the morning on the market day. On the market day, since early morning a lot of village people come to the village market to buy various commodities that are being sold in the village market.

Table 1. Some village markets (pasar desa) are found in Karangwangi Village, Cidaun Sub-district, Cianjur District, West Java, Indonesia

\begin{tabular}{|c|c|c|}
\hline Name of the village market & Location & $\begin{array}{l}\text { Weekly } \\
\text { opening day }\end{array}$ \\
\hline Pasar Desa Puncak Bayuning & Puncak Bayuning, Karangwangi sub-district, Cianjur district & Monday \\
\hline Pasar Desa Kertajati & Kertajati village, Cidaun Sub-district & Tuesday \\
\hline Pasar Desa Cimaragang & Cimaragang village, Cidaun Sub-district & Wednesday \\
\hline Pasar Lapang Jayanti & $\begin{array}{l}\text { The border between Karangwangi and Cidamar village, Cidaun Sub- } \\
\text { district }\end{array}$ & Thursday \\
\hline Pasar Desa Ciujung & The border area between Ciujung and Cidaun Sub-district & Friday \\
\hline Pasar Desa Kebon Kopi & Kebon kopi, Cidaun Sub-district & Saturday \\
\hline Pasar Desa Pelabuan Ikan Jayanti & The fish port of Jayanti, Cidaun sub-district & Sunday \\
\hline
\end{tabular}


The rural people come to the village market not only to buy various commodities but also to meet friends or relatives for eating, drinking, communicating, and sharing experiences. As the day is getting to midday, the villagers who shop gradually attenuate. Therefore, at approximately 11.00 am, market visitors usually are getting fewer and fewer, and the village market usually breaks up. When the village market finishes, the traders are usually busy collecting the remnants of their trading commodities, especially, traders who come from the city and they will move to another traditional village in another village. They go to other village markets by transporting their commodities using a pick-up car or motorcycle. However, for the local traders, after selling they usually go home to their village. Before leaving the market, the traders usually clean the tables and bamboo cots and store them in a special place in the village market.

Various commodities are commonly traded in the village markets of Cidaun Sub-district, Cianjur. For example, a variety of local foods, agricultural equipment, sandal, shoes, and cloths. In addition, various plant productions, namely fruits, vegetables, spices, and traditional medicinal ingredients are traditionally sold in the village market (Figure 4 and Figure 5).

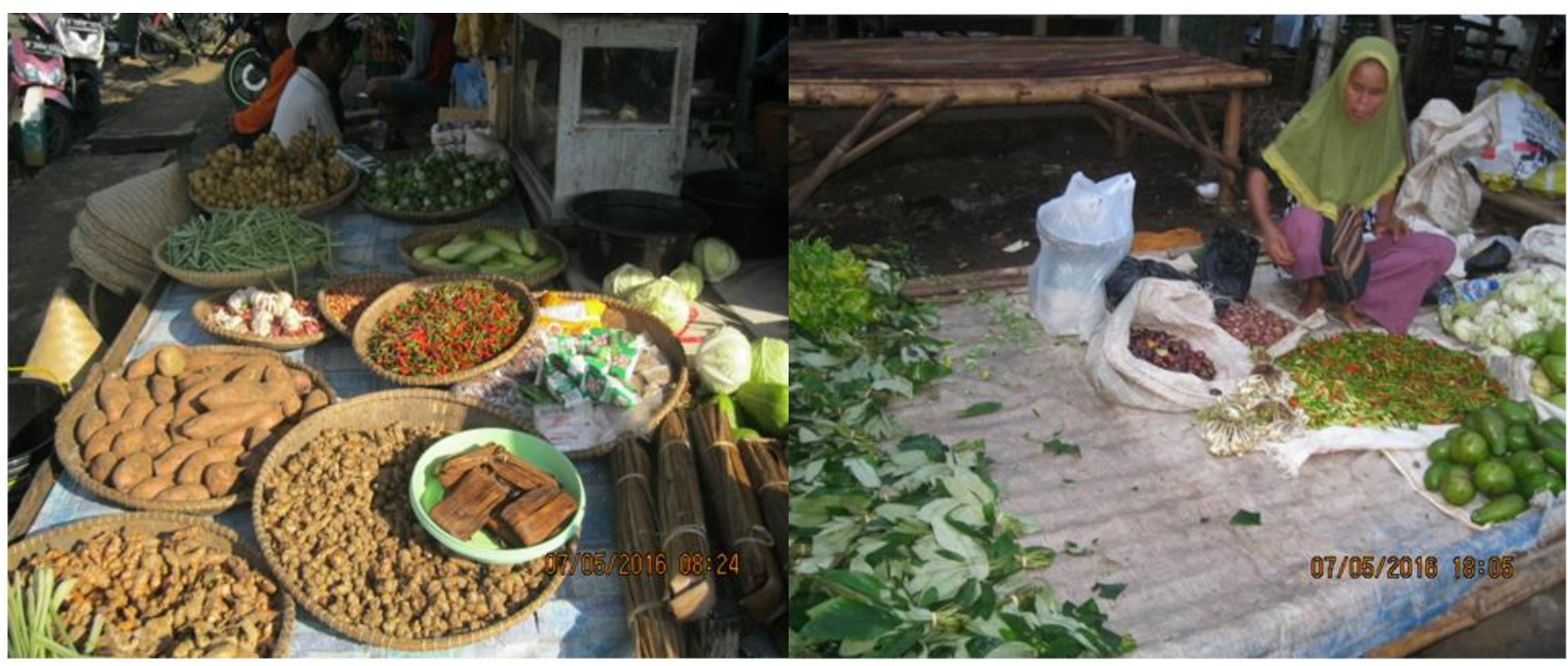

Figure 4. Various traditional medicine plants, including kencur (Kaempferia galanga L.), songgom (Kaempferia galanga L.), jengkol (Archidendron pauciflorum (Benth.) Nielsen), and alpuket (Persea americana Mill) are commonly traded in the village market of Karangwangi Village, Cidaun Sub-district, Cianjur District, West Java, Indonesia

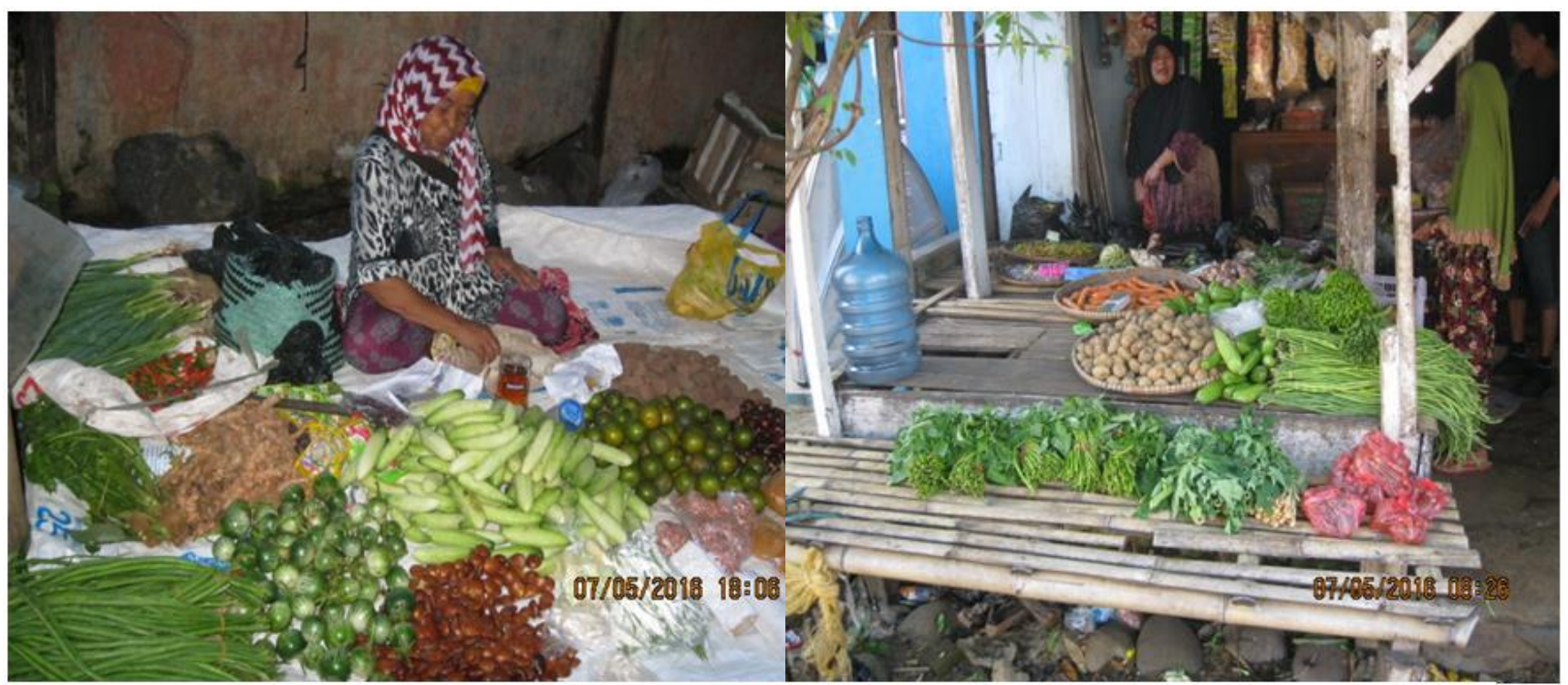

Figure 5. The traditional medicine plants and as function vegetables, including takokak (Solanum torvum Swartz), waluh siem (Sechium edule (Jacq.) Swartz), and paria (Momordica charantia L.) are predominantly traded in the village market of Karangwangi Village, Cidaun Sub-district, Cianjur District, West Java, Indonesia 


\section{Diversity of medicinal plants}

On the basis of a study on local knowledge on various diseases that are traditionally treated by medicinal plants conducted in Karangwangi Village, Cianjur, it was revealed 27 kinds of diseases and other disturbance conditions (Wicaksono 2016; Malini et al. 2017) (Table 2). Of diseases are traditionally treated by 118 species, representing 50 families of medicinal plants. This result is slightly similar to that recorded in Sukahaji village, Cibodogol, Bogor, West Java, with 117 species of medical plants to treat 23 kinds of diseases (Roosita 2008). However, the diversity of medicinal plants recorded in Karangwangi Village is higher than that in Girang Village, Bogor which recorded 43 medical plants to treat 11 kinds of diseases (Sihotang 2011), and in Bodogol, Sukabumi, West Java which recorded 93 medical plants to treat 32 kinds of diseases (Susiarti et al. 2018).

In addition to studying the various medicinal plant in Karangwangi, the research on edible plants traded in village markets of the Jayanti and Puncak Bayuning of Karangwangi Village, Cidaun Sub-district, Cianjur district, was carried out. This research documented 108 species representing 37 families of edible plants traded in village markets (Iskandar and Iskandar 2020). From the total number of 108 species, it can be revealed that 35 species, representing 23 families were materials of traditional medicine. The family of Fabaceae and Zingiberaceae have a higher number of species compared to other families (Table 3, Figure 6).

Based on our research, the diversity of medicinal plants recorded in the village market of Karangwangi Village is considered to be lower than that was documented in six traditional markets of Pati district, Central Java which recorded 126 species, representing 54 families (Irwanta et al. 2015). This result may be interpreted that herbal medicine (jamu) is predominantly made in Javanese households. Jamu is made from a mixture of ingredients or herbal that are sold in the traditional markets. Traditionally, jamu is sold by women sellers as jamu gendong and commonly sold door-to-door (Ambaretnani 2012). Because the demand for plants or herbal medicine materials has increased, the diversity of medicinal plants is higher in the traditional market of Central Java. Unlike Javanese, a lot of medicinal plants traded in the village market of Karangwangi Village are not specifically for traditional medicinal ingredients, but as main factions for spices, fruits, and vegetables.

Table 2. Various diseases and other disturbance conditions that are traditionally treated by medicinal plants based on informants of Karangwangi Village, Cidaun Sub-district, Cianjur District, West Java, Indonesia

\begin{tabular}{|c|c|c|}
\hline $\begin{array}{l}\text { Diseases and other conditions } \\
\text { local term }\end{array}$ & Common name & Cognizance \\
\hline Ambien/wasir & Hemorrhoid & Anal disorder \\
\hline Anemia/kurang darah & Anemia & The body lacks red blood cells \\
\hline Asam urat & Uric acid & $\begin{array}{l}\text { Pain in the joints of the body due to consuming foods with high } \\
\text { purine levels }\end{array}$ \\
\hline Asma & Asthma & Respiratory disorders with shortness of breath \\
\hline Batuk & Caught & Disruption of cells in later irritated esophagus \\
\hline Bronhitis & Bronchitis & Inflammation of the ducts that let air into and out of the lungs \\
\hline Darah tinggi/hipertensi & High blood pressure & $\begin{array}{l}\text { Conditions where blood pressure is higher than } 140 / 90 \text { millimeters of } \\
\text { mercury (mm HG) }\end{array}$ \\
\hline Hepatitis/Penyakit koneng & Hepatitis & Hepatitis, caused by the hepatitis B virus attacks the liver \\
\hline Demam panas & Fever & Increase in body temperature \\
\hline Kencing manis & Diabetes & High blood glucose levels \\
\hline Luka & Wound & Skin injuries such as tearing, cutting, stabbing, etc. \\
\hline Maag & Gastritis & Pain and heat in the stomach \\
\hline Melonggarkan tali lilitan pusar & $\begin{array}{l}\text { Accelerate the loosening of } \\
\text { umbilical cord }\end{array}$ & Avoiding the potential for umbilical cord twist in the baby \\
\hline $\begin{array}{l}\text { Membantu menguatkan ibu } \\
\text { baru melahirkan }\end{array}$ & Postpartum healing & Recovering the health condition of newly giving birth mothers \\
\hline Menguatkan daya tahan tubuh & Supplement & To support health and endurance \\
\hline Nyeri punggung & Low back pain & Pain or stiffness in the spine \\
\hline Penyubur air susu ibu (ASI) & Rich Brest feeding produce & Produces a lot of milk (breast milk) \\
\hline Radang kulit & Dermatitis & Inflammation of the skin with swelling and itching \\
\hline Radang perut & Gastroenteritis & Food digestive tract disorders, among others, due to viral infections \\
\hline Sakit gigi & Toothache & Pain in or around the teeth and jaw \\
\hline Sakit ginjal & Kidney diseases & Disorders occur in the kidney \\
\hline Sakit kepala & Headache & The head feels dizzy \\
\hline Sakit malaria & Malaria & $\begin{array}{l}\text { Body fever due to malaria mosquito bites that transmit the } \\
\text { plasmodium parasite }\end{array}$ \\
\hline Sakit mata & Eye diseases & Eye pain due to various causes such as viruses, bacteria and allergies \\
\hline Sakit memar & Bruised & Bruises on body parts \\
\hline Sakit mulut & Mouth sores & Pain in the mouth, like thrush and others \\
\hline Sakit perut, diare, disentri & $\begin{array}{l}\text { Stomach ache, diarrhea, } \\
\text { dysentery }\end{array}$ & $\begin{array}{l}\text { Abdominal pain or pain at defecating time due to infection by } \\
\text { bacteria }\end{array}$ \\
\hline
\end{tabular}


On the aspect of family, the Family of Zingiberace has highest number of species $(11.42 \%)$ traded in the village market of Karangwangi (Figure 6). The village market of Karangwangi and the traditional market of the Pati district is similar in the case of family of Zingiberaceae which was commonly sold in the two markets (Irawanta et al. 2015). Traditionally, plant species of Zingeberaceae family are predominantly used as raw materials of the herbal medicine in Central Java. While for Sundanese people, the plants of Zingiberaceae, including kencur or cikur (Kaempferia galanga L), jahe (Zingiber officinale Rose), kunir or koneng (Curcuma longa L) are traditionally used as medicinal plants for pregnant women (Ambaretnani 2012; Fitrianti and Partasasmita 2020; Nisyapuri et al. 2018), meanwhile, in Karya Usaha hamlet, West Kalimantan, the Zingiberazeae plant is used as an appetite enhancer for toddlers (Panjaitan et al. 2020). In addition, the people of West Java make use of Zingiberaceae plants such as Turmeric (Curcuma sp.), Ginger (Zingiber officinale), and Aromatic Ginger (Kaempferia galanga L.) to also use for disease medicine in Pelung chickens (Asmara et al. 2018). In Karangwangi, however, the rhizome of jahe (Zingiber officinale Roxb), cikur/kencur (Kaempferia galanga L.) and koneng/kunir (Curcuma longa L) is commonly used as a traditional supplement food, traditional medicine of bruise, gastritis, and stomach, respectively. According to literature, these species of Zingiberaceae are also known as a traditional medicine of various sicknesses in different ethnic groups of Indonesia (Kasahara and Hemni 1995) (Table 3).

\section{Multifunction of the medicinal plants}

Traditionally, the true Sundanese people in rural West Java are very concerned about their family's health. For example, it has been known that in Sundanese rural society, there are five main purposes of life (udagan hirup) namely: to live healthy (cageur), benevolent (bageur), clever (pinter), right (bener), and skilled (singer) (Iskandar 2018). Therefore, in the past, every family usually owned local knowledge (LK) or traditional ecological knowledge (TEK) about various diseases and their treatment techniques, including the use of various herbal medicinal plants. Villagers in the utilization of various medicinal plants are based on TEK and belief (cf. Berkes 2008; Iskandar 2018). As mentioned by Berkes (2008) TEK may be defined as 'a cumulative body of knowledge, practice, and belief, evolving by adaptive process and handed down through generations by cultural transmission, about the relationship of living beings (including humans) with one another and with the environment'. Thus, the TEK is rooted in a particular place, and generated by living in those places, and is orally transmitted through generations (Iskandar 2018). Traditionally, in the past, Sundanese people have rich TEK of various species of medicinal plants inherited from their parents and also obtaining from personal experiences (Permana 2009; Ambaretnani 2012; Suryana and Iskandar 2014; Sari et al. 2015; Susanti and Sukaesih 2015).

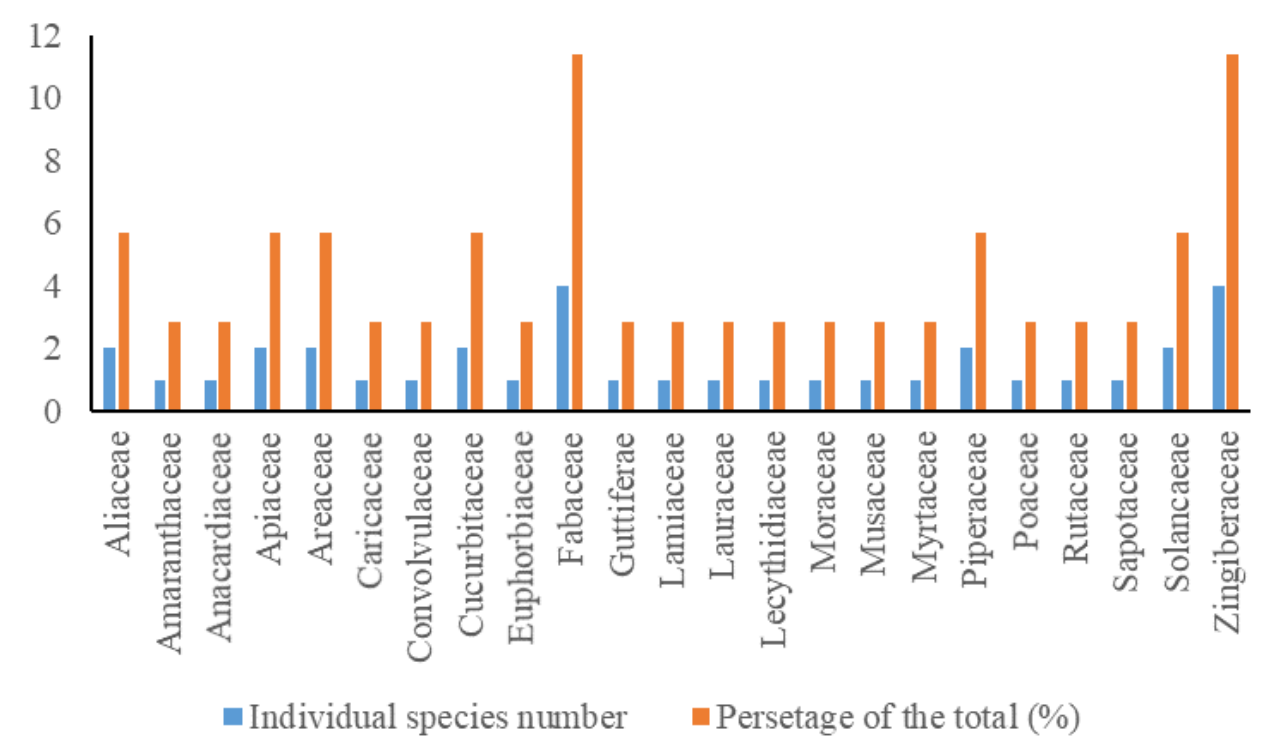

Figure 6. Family number of the medical plants traded in the market of Karangwangi Village, Cidaun Sub-district, Cianjur District, West Java, Indonesia 
Table 3. Various plants traded in village market of Karangwangi Village, Cidaun Sub-district, Cianjur District, West Java, Indonesia

\begin{tabular}{|c|c|c|c|c|c|c|}
\hline $\begin{array}{c}\text { Local name/ } \\
\text { Indonesian } \\
\text { name }\end{array}$ & Common name & Scientific name & Family name & Category & $\begin{array}{c}\text { Part of plant: } \\
\text { traditional medicinal } \\
\text { ingredient }\end{array}$ & $\begin{array}{l}\text { Medicinal herbal index in Indonesia } \\
\text { (Kasahara and Hemni 1995) }\end{array}$ \\
\hline Alpuket & Avocado & Persea americana Mill & Lauraceae & Medicine, fruit & $\begin{array}{l}\text { Leaves: high blood } \\
\text { pressure, gastritis }\end{array}$ & Leaves: diuretic \\
\hline Antanan & Gotu kola & Centella asiatica $\mathrm{CA}$ & Apiaceae & Medicine, vegetable & $\begin{array}{l}\text { Leaves: wound, } \\
\text { gastritis }\end{array}$ & $\begin{array}{l}\text { All part: against cough, pyrexia, calculus, gall bladder } \\
\text { disease }\end{array}$ \\
\hline Aren, Kawung & Sugar palm & $\begin{array}{l}\text { Arenga pinnata } \\
\text { (Wurmb.) Merr. }\end{array}$ & Arecaceae & Medicine, fruit & Root: low back pain & Root: against calculus vesicalis, renal calculus \\
\hline $\begin{array}{l}\text { Bawang merah, } \\
\text { Bawang beureum }\end{array}$ & Bulb onion & $\begin{array}{l}\text { Allium cepa } L . \\
\text { var.ascalonicum } L \text {. }\end{array}$ & Alliaceae & Medicine, spice & Bulb: fever, wound & Bulb: eaten \\
\hline $\begin{array}{l}\text { Bawang putih, } \\
\text { Bawang bodas }\end{array}$ & Garlic & Allium sativum $\mathrm{L}$. & Alliaceae & Medicine, spice & $\begin{array}{l}\text { Bulb: high blood } \\
\text { pressure }\end{array}$ & $\begin{array}{l}\text { Bulb: against cough, asthma, hyperemesis, otis interna, } \\
\text { scabies, pityriasis versicolor, coryza, pruritus, antidote } \\
\text { for poison insect bite, hypotension, cholera, as } \\
\text { anthelminthic, against migraine, dysmenorrhea, } \\
\text { impotency }\end{array}$ \\
\hline Bayam, Bayem & $\begin{array}{l}\text { Three colored } \\
\text { amaranth }\end{array}$ & Amaranthus tricolor $\mathrm{L}$. & Amaranthaceae & Medicine, vegetable & Leaves: anemia & \\
\hline Cabe hejo & Pepper & Capsicum аппиит $\mathrm{L}$ & Solanaceae & Medicine, spice & Fruit: wounds & $\begin{array}{l}\text { Fruit: against anorexia, hypotension leaves: against } \\
\text { furuncles, ulcus, colic }\end{array}$ \\
\hline Gedang, Pepaya & Papaya & Carica papaya $\mathrm{L}$ & Caricaceae & Medicine, fruit & $\begin{array}{l}\text { Root: malaria, kidney } \\
\text { disease, rich } \\
\text { breastfeeding } \\
\text { produce }\end{array}$ & $\begin{array}{l}\text { Leaves: against alimentary toxication, malaria, tormina, } \\
\text { rheumatism, catch-cold, heimentes, anorexia, and } \\
\text { acholia. } \\
\text { Latex: against renal colic, bladder colic, poisonous } \\
\text { snake bite, eternal paralysis, cancer } \\
\text { Fruit: against cardiac paint, obstipation and vertigo }\end{array}$ \\
\hline $\begin{array}{l}\text { Huwi Boled, Ubi } \\
\text { jalar }\end{array}$ & Sweet potato & $\begin{array}{l}\text { Ipomoea batatas }(\mathrm{L} .) \\
\text { Lam }\end{array}$ & Convolvulaceae & $\begin{array}{l}\text { Medicine, } \\
\text { carbohydrate staple } \\
\text { food }\end{array}$ & $\begin{array}{l}\text { Leaves: high blood } \\
\text { pressure }\end{array}$ & Tuber: food \\
\hline Jahe & Ginger & $\begin{array}{l}\text { Zingiber officinale } \\
\text { Roxb. }\end{array}$ & Zingiberaceae & Medicine, spices & Rhizome: supplement & $\begin{array}{l}\text { Rhizome: against anorexia, dyspepsia, vertigo, } \\
\text { rheumatism, phthisis, pruritus, cholera, antidote for } \\
\text { snakebite, diphtheria, coryza, neurasthenia, } \\
\text { hyperemesis, distortion, swellings }\end{array}$ \\
\hline $\begin{array}{l}\text { Jambu mente, } \\
\text { Jambu monyet }\end{array}$ & Cashew nut & $\begin{array}{l}\text { Anacardium occidentale } \\
\mathrm{L}\end{array}$ & Anacardiaceae & $\begin{array}{l}\text { Medicine, } \\
\text { vegetables }\end{array}$ & Leaves: mouth sores & $\begin{array}{l}\text { Leaves: against combustion, stamation adema, } \\
\text { adenoiditis. Latex from young fruits: against levra, } \\
\text { ulcus, uteritis, veruca, naevus. Seed oil: against poison } \\
\text { from food. Root/bark/leaves: against dysentery }\end{array}$ \\
\hline Jengkol & Jengkol & $\begin{array}{l}\text { Achidendron } \\
\text { pauciflorum (Benth.) } \\
\text { Nielsen }\end{array}$ & Fabaceae & Medicine, vegetable & Fruit peel: diabetes & Seed: eaten bark; source of tannin \\
\hline
\end{tabular}




\begin{tabular}{|c|c|c|c|c|c|c|}
\hline Jeruk nipis & & $\begin{array}{l}\text { Citrus aurantifolia } \\
\text { (Christm) Swingle }\end{array}$ & Rutaceae & Medicine, vegetable & $\begin{array}{l}\text { Fruit: cough, } \\
\text { toothache }\end{array}$ & Fruit: food, flavoring \\
\hline $\begin{array}{l}\text { Kacang hijau, } \\
\text { Kacang hejo }\end{array}$ & Mungbean & $\begin{array}{l}\text { Vigna radiata }(\mathrm{L} .) \\
\text { Wilczek }\end{array}$ & Fabaceae & $\begin{array}{l}\text { Medicine, } \\
\text { Carbohydrate } \\
\text { Staple food }\end{array}$ & Seed: gastritis & Seed: food \\
\hline Kacang suuk & Peanut & Arachis hypogaea $\mathrm{L}$ & Fabaceae & $\begin{array}{l}\text { Medicine, } \\
\text { vegetable, spice }\end{array}$ & $\begin{array}{l}\text { Seed: postpartum } \\
\text { healing }\end{array}$ & $\begin{array}{l}\text { Seed oil: against starvation edema, beriberi, and } \\
\text { constipation }\end{array}$ \\
\hline Kencur, Cikur & Aromatic ginger & Kaempferia galanga $\mathrm{L}$. & Zingiberaceae & Medicine, spice & Rhizome: bruised & $\begin{array}{l}\text { Rhizome: against coryza, tetanus, stomatitis, abscess, } \\
\text { hyperemesis, muscular sturdy, colic, food poisoning }\end{array}$ \\
\hline Koneng, Kunyit & Tumeric & Curcuma longa $\mathrm{L}$. & Zingiberaceae & Medicine, spice & $\begin{array}{l}\text { Rhizome: gastritis, } \\
\text { stomachache }\end{array}$ & $\begin{array}{l}\text { Rhizome: apendictis, uteritis, angina, icterus, febrilis, } \\
\text { infectious, asthma, ulcus, pruritus, abscess, rheumatism, } \\
\text { rhinitis, colic, constipatio, trachoma, anemia, } \\
\text { hypotension, eczema, febris puerperalis, diarrhea, } \\
\text { morbilli, vertigo, icterus (jaundice), leucorrhea, scabies, } \\
\text { dysentery }\end{array}$ \\
\hline Laja & Galangal & $\begin{array}{l}\text { Alpinia galanga }(\mathrm{L} .) \\
\text { Swartz }\end{array}$ & Zingiberaceae & Medicine, spice & Rhizome: cough & $\begin{array}{l}\text { Rhizome: against eczema, bronchitis, coryza, morbilli, } \\
\text { pityriasis versicolor, otitis interna, gastritis, ulcus, } \\
\text { cholera, tinea furfuracea }\end{array}$ \\
\hline $\begin{array}{l}\text { Manggu, } \\
\text { Manggis }\end{array}$ & Mangosteen & $\begin{array}{l}\text { Garcina mangostana } \\
\text { Linn }(\mathrm{Gml})\end{array}$ & Guttiferae & Medicine, fruit & $\begin{array}{l}\text { Fruit peel: high blood } \\
\text { pressure }\end{array}$ & $\begin{array}{l}\text { Sacorcarp: against diarrhea, adeuoiditis, dysentery, } \\
\text { extrual, hemorrhoids, ulcus purulent, ptyalism } \\
\text { (hypersaliva), leucorrhea }\end{array}$ \\
\hline Merica, Pedes & Black pepper & Piper nigrum $\mathrm{L}$. & Piperaceae & Medicine, spice & $\begin{array}{l}\text { Leaves: postpartum } \\
\text { healing }\end{array}$ & $\begin{array}{l}\text { Fruit: menstruation disorder, cold, influenza, ringworm, } \\
\text { and hypotension }\end{array}$ \\
\hline Nangka & Jackfruit & $\begin{array}{l}\text { Artocarpus } \\
\text { heterophyllus Lam }\end{array}$ & Moraceae & Medicine, fruit & $\begin{array}{l}\text { Leaves: gastritis, } \\
\text { cough }\end{array}$ & $\begin{array}{l}\text { Leaves: against abscess } \\
\text { Seed: against diarrhea } \\
\text { Root: against febris and malaria }\end{array}$ \\
\hline Paria & Bitter gourd & Momordica charantia L. & Cucurbitaceae & Medicine, vegetable & $\begin{array}{l}\text { Leaves: fever, } \\
\text { diabetes }\end{array}$ & $\begin{array}{l}\text { Leaves: against lever liver disease, intestinal worm, as } \\
\text { emetic, purgant, depurative, lactagogue, against } \\
\text { anorexia, headache } \\
\text { Fruit: as depurative }\end{array}$ \\
\hline $\begin{array}{l}\text { Peuteuy selong, } \\
\text { Lamtoro }\end{array}$ & - & $\begin{array}{l}\text { Leucaena glauca } \\
\text { (Willd.)Benth. }\end{array}$ & Fabaceae & Medicine, vegetable & Seed: diabetes & $\begin{array}{l}\text { Seed: as anthelminthic, against nephritis, and diabetes } \\
\text { mellitus } \\
\text { Leaves: against vulnus incisinum, and small fox }\end{array}$ \\
\hline $\begin{array}{l}\text { Pisang Ambon, } \\
\text { Cau Ambon }\end{array}$ & Banana & Musa x paradisiaca $\mathrm{L}$ & Musaceae & Medicine, fruit & Stem: wound & $\begin{array}{l}\text { Root and bulb: against antidote for snake bite } \\
\text { Fruit: against catarrhous intestinalis, hemorrhoids, } \\
\text { aphatae tropicae }\end{array}$ \\
\hline Salak & Snakeskin palm & $\begin{array}{l}\text { Salacca zalacca (J. } \\
\text { Gaerth) Voss }\end{array}$ & Arecaceae & Medicine, fruit & Shoot: urinary disease & Fruit/seed: against diarrhea, colic \\
\hline Salam & $\begin{array}{l}\text { Indonesian bay- } \\
\text { leaf }\end{array}$ & $\begin{array}{l}\text { Syzygium polyanthum } \\
\text { (Wight) Walp }\end{array}$ & Myrtaceae & Medicine, spice & $\begin{array}{l}\text { Leaves: high blood } \\
\text { pressure }\end{array}$ & Leaves: against diarrhea and weak stomach \\
\hline Sawo & Sapodilla & $\begin{array}{l}\text { Manilkara achras (Mill) } \\
\text { Fosberg }\end{array}$ & Sapotaceae & Medicine, fruit & Leaves: diarrhea & $\begin{array}{l}\text { Bark: against dysentery } \\
\text { Flower: against febris }\end{array}$ \\
\hline Seledri & Celery & Apium graviolens $\mathrm{L}$. & Apiaceae & Medicine, vegetable & $\begin{array}{l}\text { High leaves: blood } \\
\text { pressure }\end{array}$ & All part: eaten as vegetable \\
\hline
\end{tabular}




\begin{tabular}{|c|c|c|c|c|c|c|}
\hline Sereh, Serai & Watermelon & $\begin{array}{l}\text { Cymbopogon nardus } \\
\text { (L.) Rendle }\end{array}$ & Poaceae & Medicine, spice & Leaves: toothache & Leaves: perfume material \\
\hline Sirih, Seureuh & Betel pepper & Piper betle $\mathrm{L}$ & Piperaceae & Medicine, to betel & Leaves: wound & $\begin{array}{l}\text { Leaves: boil, cough, rheumatism, nose bleeding, cardiac } \\
\text { troubles, giddiness, galactorrhoea, conductivities, dry } \\
\text { cough, foetor ex ore, febris puerperalis, leucorrhoea }\end{array}$ \\
\hline $\begin{array}{l}\text { Singkong, } \\
\text { Sampeu }\end{array}$ & Cassava manioc & $\begin{array}{l}\text { Manihot esculenta } \\
\text { Crantz. }\end{array}$ & Euphorbiaceae & $\begin{array}{l}\text { Medicine, } \\
\text { Carbohydrate } \\
\text { Staple food }\end{array}$ & $\begin{array}{l}\text { Tuber: anemia, } \\
\text { gastritis }\end{array}$ & Tuber: food \\
\hline Songgom & Barringtonia & $\begin{array}{l}\text { Barringtonia insignis } \\
\text { Miq }\end{array}$ & Lecythidaceae & Medicine, vegetable & $\begin{array}{l}\text { Leaves: postpartum } \\
\text { healing }\end{array}$ & Root bark: fish poisoning and glycoside \\
\hline $\begin{array}{l}\text { Surawung, } \\
\text { Kemangi }\end{array}$ & Basil & Ocimum americanum $\mathrm{L}$. & Lamiaceae & Medicine, vegetable & Leaves: dermatitis & $\begin{array}{l}\text { Leaves: against febris, coryza, rheumatism, nervous } \\
\text { indrasia, lactation troubles, aphtae tropicae, pityriasis } \\
\text { versicolor, tympanitis, hyperemesis } \\
\text { Seeds: against palpitate cordis, constipation, gonorrhea }\end{array}$ \\
\hline Takokak & Turkey berry & Solanum torvum Swartz & Solanaceae & Medicine, vegetable & $\begin{array}{l}\text { Fruit: high blood } \\
\text { pressure }\end{array}$ & $\begin{array}{l}\text { Fruit: against anorexia, hypertension, clavus } \\
\text { Laves: against palpitasio cordis, vertigo }\end{array}$ \\
\hline Waluh siem & Chayote & $\begin{array}{l}\text { Sechium edule (Jacq.) } \\
\text { Swartz }\end{array}$ & Cucurbitaceae & Medicine, vegetable & $\begin{array}{l}\text { Leaves: fever, } \\
\text { gastroenteritis }\end{array}$ & $\begin{array}{l}\text { Fruit: against aphthae tropicae, tropical sprue, and } \\
\text { scurvy }\end{array}$ \\
\hline
\end{tabular}


Table 4. Some diseases and other disturbance conditions that are predominantly treated by medicinal plants traded in the village market of Karangwangi Village, Cidaun Sub-district, Cianjur District, West Java, Indonesia

\begin{tabular}{|c|c|c|c|}
\hline $\begin{array}{l}\text { Local name of diseases } \\
\text { and disturbance } \\
\text { conditions (Indonesian) }\end{array}$ & $\begin{array}{l}\text { Medical } \\
\text { common } \\
\text { name }\end{array}$ & $\begin{array}{l}\text { Plant species } \\
\text { number used }\end{array}$ & Plant species \\
\hline Anemia & Anemia & 2 & $\begin{array}{l}\text { Bayem (Amaranthus tricolor L), Singkong (Manihot esculenta } \\
\text { Crantz) }\end{array}$ \\
\hline Batuk & Cough & 3 & $\begin{array}{l}\text { Jeruk nipis (Citrus aurantifolia (Christm) Swingle), Laja (Alpinia } \\
\text { galanga (L.) Swartz), Nangka (Artocarpus heterophyllus Lam) }\end{array}$ \\
\hline Demam panas & Fever & 3 & $\begin{array}{l}\text { Bawang merah (Allium cepa L), Paria (Momordica charantia L), } \\
\text { Waluh siem (Sechium edule (Jacq.) Swartz) }\end{array}$ \\
\hline Kencing manis & Diabetes & 3 & $\begin{array}{l}\text { Jengkol (Achidendron pauciflorum (Benth.) Nielsen), Paria } \\
\text { (Momordica charantia L), Peuteuy selong (Leucaena glauca (Willd.) } \\
\text { Benth) }\end{array}$ \\
\hline Luka & Wound & 3 & $\begin{array}{l}\text { Antanan (Centella asiatica CA), bawang merah (Allium cepa L), } \\
\text { Cabe hejo (Capsicum annum L), Sirih (Cymbopogon nardus (L.) } \\
\text { Rendle) }\end{array}$ \\
\hline Maag & Gastritis & 7 & $\begin{array}{l}\text { Alpuket (Persea americana Mill), Antanan (Centella asiatica) Merr), } \\
\text { kacang hijau (Vigna radiata (L.) Wilczek), Kunir (Curcuma longa } \\
\text { L), Nangka (Artocarpus heterophyllous Lam), Pisang ambon (Musax } \\
\text { paradisiaca L), Singkong (Manihot esculenta Crantz) }\end{array}$ \\
\hline Malaria & Malaria & 1 & Papaya (Carica papaya $\mathrm{L})$ \\
\hline Memar & Bruiced & 1 & Kencur (Kaempferia galanga $\mathrm{L})$ \\
\hline $\begin{array}{l}\text { Menguatkan daya tahan } \\
\text { tubuh }\end{array}$ & Supplement & 1 & Jahe (Zingiber officinale Roxb) \\
\hline $\begin{array}{l}\text { Menguatkan ibu baru } \\
\text { melahirkan }\end{array}$ & $\begin{array}{l}\text { Postpartum } \\
\text { healing }\end{array}$ & 3 & $\begin{array}{l}\text { Kacang suuk (Arachis hypogaea L), Merica (Piper nigrum L), } \\
\text { Songgom (Barringtonia insignis Miq) }\end{array}$ \\
\hline Nyeri punggung & Low back pain & 1 & Aren (Arenga pinnata (Wurmb) \\
\hline Penyakit kencing & Urinary disease & 1 & Salak (Salacca zalacca (J. Gaerth) Voss) \\
\hline Penyubur asi & $\begin{array}{l}\text { Rich brest } \\
\text { feeding produce }\end{array}$ & 1 & Pepaya (Carica papaya $\mathrm{L})$ \\
\hline Radang kulit & Dermatitis & 1 & Kemangi (Ocimum americanum $\mathrm{L})$ \\
\hline Radang perut & Gastroenteritis & 1 & Waluh siem (Sechium edule (Jacq.) Swartz) \\
\hline Sakit gigi & Toothache & 2 & $\begin{array}{l}\text { Jeruk nipis (Citrus aurantifolia (Christm) Swingle), Sereh } \\
\text { (Cymbopogon nardus (L.) Rendle) }\end{array}$ \\
\hline Sakit ginjal & Kidney disease & 1 & Papaya (Carica papaya $\mathrm{L})$ \\
\hline Sakit mulut & Mouth sores & 1 & Jambu mente (Anacardium occidentale $\mathrm{L})$ \\
\hline Sakit perut & Stomachache & 2 & Kunyit (Curcuma longa L), Sawo (Manilkara achras (Mill) Fosberg) \\
\hline Tekanan darah tinggi & $\begin{array}{l}\text { High blood } \\
\text { pressure }\end{array}$ & 6 & $\begin{array}{l}\text { Alpuket (Persea americana Mill), Bawang putih (Allium sativum } \mathrm{L}) \text {, } \\
\text { Ubi jalar (Ipomoea batatas L) (Lam), Manggis (Garcinia } \\
\text { mangostana Linn }(\mathrm{Gml}) \text { ), Salam (Syzygium polyanthum (Wight) } \\
\text { Walp), Saledri (Apium graveolens L), Takokak (Solanum torvum } \\
\text { Swartz) }\end{array}$ \\
\hline Total & & 35 & \\
\hline
\end{tabular}

Based on the informant's perception, it has been revealed that twenty kinds of diseases and disturbance conditions are commonly treated by using species of medicinal plants. Among the various diseases, gastritis (maag) disease uses most species of medicinal plants with 7 species $(20 \%)$, while high blood pressure uses 6 plant species $(17 \%)$, and other diseases use between 1 and 3 species (Table 4).

In general, the number of diseases known to the informants of Karangwangi Village is not much different from the results of research in other places in West Java, namely Cibunar village, Rancakalong, Sumedang (23 diseases) (Suryana and Iskandar 2014), Padalarang Karst area, West Bandung (28 diseases) (Rismata 2012), and Bodogol area, around Mount Pangrango, Sukabumi (32 diseases) (Susiarti et al. 2018); Miduana Hamlet, around Gunung Simpang Nature Reserve, Balegede village,
Naringgul District (14 diseases) (Handayani 2015); and Sukajadi village, Tamansari sub-District, Bogor district (23 diseases) (Roosita et al. 2008). Some common illnesses that occurred in Karangwangi Village and in other places of West Java are cough, stomach ache, fever, toothache, and high blood pressure.

Based on discussion, it can be found that a total of 35 species of medicinal plants generally have multi-functions, namely as 'traditional medicine and vegetables' consisting of 12 species (34.28\%), as 'traditional medicine and spice' consisting of 10 species (28. 57\%), and as 'traditional medicine and fruit' consisting of 8 species $(22.85 \%)$ (Table $5)$. A number of species of vegetable plants as well as dominant medicinal plant were recorded in the village market of Karangwangi Village as well as documented in some traditional markets in the city of Bandung, such as the Ujung Berung market, because Sundanese people have 
a fondness for consuming vegetables in their daily food menu and Sunda region is the center of vegetable cultivation (Hendarningrum 2018; Iskandar et al. 2018). According to Iskandar et al. (2018), Sundanese people in West Java have been known to have a tradition of consuming various kinds of vegetables, including fresh vegetables. For example, in various Sundanese restaurants, various vegetables are usually served in raw or fresh form combined with chili sauce, such as leunca (Solanum americanum Mill), eggplant (Solanum melongena L), cucumber (Cucumis sativus L), surawung (Ocimum basilicum L), and tespong (Oenanthe javanica DC). Besides, the Sundanese food menu, such as ulukutek leunca, utilizes fresh leunca vegetables with a mixture of various cooked spices (Mulyanto et al. 2018). Not only that, some types of distinctive culinary in Sundanese people, such as karedok and loték, with basic ingredients of common vegetable plants, are also served for Sundanese food. The habit of Sundanese people consuming vegetable species is a tradition of intergenerational inheritance and a healthy lifestyle until now (Hendariningrum 2018). Consuming different types of vegetables is very good for health because these types of vegetable plants contain low energy, but are rich in nutrients, vitamins, and minerals (Siemonsma and Piluek 1994). Several species of plants were used as lalab by the Sundanese, such as antanan (Centella asiatica (L) Urb), katuk (Sauropus androgynous (L) Merr), leunca (Solanum americanum Mill), reundeu (Staurogyne elongata Kuntze), and mareme (Glochidion borneense (Mull. Arg) as well as a traditional medicine ingredient (Handayani 2015; Ain et al. 2016).

Besides the cultural influence of fondness for consuming vegetables, some mountainous regions of West Java, such as Lembang, Ciwidey, Pangalengan, and Garut, are very conducive to the cultivation of vegetable crops and are known to be the centers of vegetables in West Java (Iskandar et al. 2018). Given the high demand for vegetables, and vegetable supply is also suitable to grow in the highlands of West Java. Therefore, the species of vegetable plants, including medicinal plants, are widely traded in rural markets or traditional markets in West Java.

\section{Organ part used as medicinal plants}

Of 35 species of medicinal plants, the main plant parts used as traditional medicinal ingredients for the treatment of 20 diseases are leaves with 17 species (48.57\%), fruit with 4 species $(11.42 \%)$, and rhizome with 4 species $(11.42 \%)$ (Table 6). These results are in line with several studies on medicinal plants in several regions in West Java, that plant parts are widely used as ingredients of traditional medicine (Roosita et al. 2007; Rismaita 2012; Handayani 2015; Malini et al. 2017; Susiarti et al. 2018). Leaves are the main place for metabolism process so there will be relatively many complex compounds in the leaves. Additionally, taking leaves from living plant for traditional medicinal ingredients give no damage nor death of plants so that plant leaves can be harvested sustainably. Conversely, harvesting the root, stems, bark, and tubers for medicinal ingredients can damage or kill the plant (Swanson 1998).
Table 5. The medicinal plants and multifunction, including as vegetable, spice, and fruit of Karangwangi Village, Cidaun Subdistrict, Cianjur District, West Java, Indonesia

\begin{tabular}{lcc}
\hline The main function of plant & $\begin{array}{c}\text { Species } \\
\text { number }\end{array}$ & $\begin{array}{c}\text { Percentage of } \\
\text { the total (\%) }\end{array}$ \\
\hline Traditional medicine and vegetable & 12 & 34.28 \\
Traditional medicine and spice & 10 & 28.57 \\
$\begin{array}{l}\text { Traditional medicine and fruit } \\
\text { Traditional medicine and additional } \\
\text { staple food }\end{array}$ & 8 & 22.85 \\
$\begin{array}{l}\text { Traditional medicine and } \\
\text { vegetable, spice }\end{array}$ & 1 & 8.57 \\
$\begin{array}{l}\text { Traditional medicine and to beetle } \\
\text { ingredient }\end{array}$ & 1 & 2.85 \\
Total species & 35 & 2.85 \\
\hline
\end{tabular}

Table 6. Various parts of medicinal plants traded in the village market of Karangwangi Village, Cidaun Sub-district, Cianjur District, West Java, Indonesia

\begin{tabular}{lcc}
\hline Plant parts & Species number & Percentage to total \\
\hline Leaves & 17 & 48.57 \\
Fruit & 4 & 11.42 \\
Rhizome & $4 \mathrm{~S}$ & 11.42 \\
Root & 2 & 5.71 \\
Bulb & 2 & 5.71 \\
Fruit peel & 2 & 5.71 \\
Seed & 2 & 5.71 \\
Stem & 1 & 2.85 \\
Shoot & 1 & 2.85 \\
Total species & 35 & 100.00 \\
\hline
\end{tabular}

Table 7. Origin of medicinal plants traded in the village market of Karangwangi Village, Cidaun Sub-district, Cianjur, West Java, Indonesia

\begin{tabular}{lcc}
\hline Origin of medicinal plant & $\begin{array}{c}\text { Species } \\
\text { number }\end{array}$ & $\begin{array}{c}\text { Percentage of the } \\
\text { total (\%) }\end{array}$ \\
\hline Village itself & 23 & 65.71 \\
Wholesale in the central & 9 & 25.71 \\
market of the city & 3 & \\
Local and city & 35 & 8.57 \\
Total species & 100.00 \\
\hline
\end{tabular}

\section{Origin of medicinal plant species on the village market}

Various species of medicinal plants traded in the village market in Karangwangi Village can be distinguished mainly from 3 main sources, namely from the village itself, from the city, and from both village and city (Table 7).

The species of medicinal plants from the village are usually obtained from the agricultural products of the rural people produced from some types of agroecosystems, namely homegarden, garden, mixed-garden, and wet-rice field. Various plants are predominantly planted in the village homegarden, namely fruits, vegetables, spices, and traditional medicines (Iskandar and Iskandar 2016). Various medicinal plants from the homegarden systems are 
mainly used for daily need of the village households, and readily harvested any time throughout the year. Additionally, various medicinal plants are planted in garden and mixed-garden that are predominantly used for daily needs of the households and some surpluses are usually sold to middlemen or to the village market. Some wild medicinal plant species, including antanan/gotu kola (Centella asiatica $\mathrm{CA}$ ) and songgom (Barringtonia insignis Miq) are harvested from the wet-rice field and the forest, respectively.

Meanwhile, species of medicinal plants traded in the village market come from cities, usually in the form of vegetables and large fruits from several vegetable farming centers in West Java, such as the Ciwidey and the Caringin wholesale market, Bandung city.

Various species of plants, including medicinal plants, are traded in the village markets in Karangwangi Village through the trade chain. The species of medicinal plants originating from the village, i.e. from agricultural productions of village farmers, are sold to village middlemen, and then they are traded in village markets. Meanwhile, various species of medicinal plants from a city that are traded in the village market, usually are brought into the village market of Karangawangi, Cidaun, Cianjur by middlemen who bought various medicinal from the market centers, such as Ciwidey and Caringin Bandung city (Figure 7).

Some studies on trading various species of edible plants, such as fruits, vegetables, cooking spices, and traditional medicines in the urban traditional markets in Indonesia have been carried out by scholars (Supangkat 2012; Susanti 2015; Yurlisa et al. 2017; Maspaitella et al. 2018). In addition, studies on medicinal plants traded in
Indonesia and other countries have been undertaken by scholars (Idu et al. 2010; Radriamiharrisoa et al. 2015; Silalahi et al. 2015; Irwanta et al. 2015). However, research on trading edible plants that function as food, as fruits, as vegetables, as cooking spices, and also at the same time as traditional medicines in both traditional urban markets and village markets in Indonesia is still very rare.

Based on our study, it can be seen that the various species of edible plants traded in the traditional markets of Karangwangi Village have important dual function, i.e. as food and as traditional medicine materials for village people. Culturally, the Sundanese ethnic group in Southern Cianjur, or in entire West Java has been very well known as an ethnic group in Indonesia who likes to consume fresh vegetables on a daily diet (Iskandar et al. 2018). So, it is not surprising that vegetable plants with their secondary function as traditional medicinal ingredients are dominantly traded in traditional markets. For example, paria or pare or bitter melon (Momordica charantia), a member of Cucurbitaceae family, is one of the vegetable plants that has been culturally used as the main vegetable menu in Sundanese people's daily food. Also, the bitter melon is traditionally used by local people in Karangwangi Village as traditional medicines, including the leaves which are commonly used as traditional medicines for fever and diabetes. While, based on documentation of medicinal plants in Indonesia, Momordica charantia plants have indeed been categorized as traditional medicinal plants, in which the leaves are used to cure liver disease, intestinal worm, as an emetic, pungent, depurative, lactagogue, against anorexia, headache, and their fruits are as depurative agent (Kasahara and Hemini 1995).

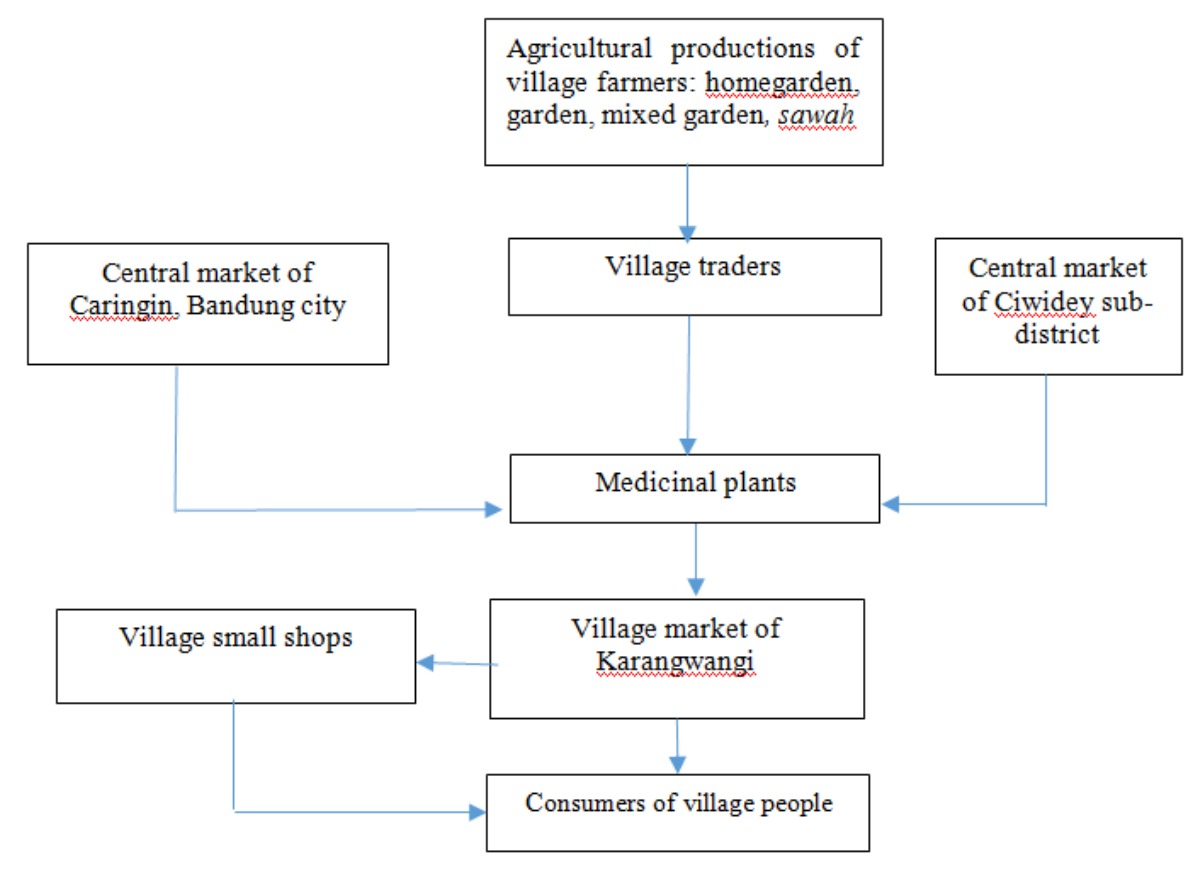

Figure 7. Trading change of medicinal plants traded in village market of Karangwangi Village, Cidaun Sub-district, Cianjur District, West Java, Indonesia 
Indeed, based on the result of scientific studies of Momordica charantia which is scientifically known to have chemical compounds namely alkaloids, including momordicin and charantin, chorine, and monochanis the form of extracts (primary from fruit) is being used to treat many diseases such as diabetes, dyslipidemia, microbial infections, and it is potentially as a cytotoxic agent for certain types of cancer (Das et al. 2015). So, scientific studies on Momordica charantia shows that the local knowledge of the Karangwangi Village community about the use of this plant as diabetes treatment can be scientifically validated.

Undoubtedly, by trading the species of edible plants, the traditional village markets, such as the traditional markets in Karangwangi Village have been playing a very important role in the socio-economic function of rural communities for a long time. These markets can also support the sustainability of food sources, and the health of villagers. For the health of rural communities, for example, various edible plants traded in traditional village markets also function as an important source of traditional medicine i.e. as complementary and alternative medicine (CAM) in Indonesia (cf. Ambaretnani 2012; Iskandar 2018).

Accordingly, it is very unfortunate that nowadays, the traditional village markets in Indonesia come to an end due to the intensive penetration of the market economy system into rural areas and government policies to give more incentives to the development of a market economy system, and to give disincentives to traditional village markets, that it can be very detrimental to socio-economy, social culture and biodiversity conservation. Because the loss of village markets can also eliminate the benefits of village markets as a means of economic activity, food sources, and sources of traditional medicines for the village, and the conservation of a variety of rural local plant species.

Moreover, the decreasing or loss of village traditional markets may cause a decrease in the local varieties (landraces) of rural plant species and traditional ecological knowledge (TEK) of those species. Thus, the influence of government policies on the development of a market economic system can urge the existence of traditional markets, and also affect the landraces of local plant species and its local knowledge of the rural people. An example is given in Vietnam in which $80 \%$ of the Vietnamese are dependent on traditional botanical medicines as their primary means of health care, but the economic liberation of the Vietnamese government has led to changes in supply and demand for medicinal plants that are commonly traded by women in the mountains of northern Vietnam. Thus, the traditional botanical medicine in the mountains of northern Vietnam has been shaped by constraints and opportunities that arise from interactions between biocultural knowledge, institutions at the local level, and political-economic processes at state and international levels, including rapid economic growth of markets, intensively penetrated to rural area (Sowerwine 2004).

In relation with supplying traditional medicinal materials in rural areas, it is generally not possible for rural residents who become traders in traditional markets to conserve various medicinal plants for traditional medicinal purposes as complementary and alternative medicine (CAM) (Ambaretnani 2012; Iskandar 2018) for the system of reproduction in rural areas, when trading these species of plants the traditional medicinal ingredients gives no benefit for traders and become a source of income for rural families. Therefore, conservation of medicinal plant species in the countryside will be done by the villagers independently and sustainably, especially if the villagers feel that they receive significant health benefits from locally grown medicinal plants. Besides, the village people receive an appreciable income from the sale of locally grown medical plants (Iskandar et al. 2018).

Based on the results of this study, it can be concluded that although in many villages in West Java, they have come to extinction, in some villages, such as in Karangwangi Village, Cidaun district, the village markets are still found. The village market is open once a week. Many species of plants, including traditional medicinal plants, are traded in the village market. The results of the study have documented 35 species, representing 23 species of medicinal plants commonly traded in the village market in Karangwangi Village, Cidaun district, Cianjur, West Java.

Of these medicinal plants are commonly used by Karangwangi people to treat 20 kinds of diseases and other disturbance conditions, namely anemia, cough, fever, diabetes, injuries, gastritis, malaria, bruised, supplements, toothache, kidney disease, mouth sores, stomachache, high blood pressure, past partum healing, low back pain, urinary disease, rich breastfeeding production, dermatitis, and gastroenteritis. In general, these species of medicinal plants have multi-function, namely as medicine and vegetables, as medicines and herbs, as medicines and spices, as medicines and fruits, as medicines and carbohydrate staple foods, as medicines, vegetables and spices, and as medicine and to betel ingredient.

The results of this study reveal that the village market has an important role not only in socio-economic and cultural functions but also an essential function for the conservation of various biodiversity, including various biodiversity of traditional plant species. Rare or even extinct medicinal plant species in the agricultural system of rural areas and their scarcity trade in traditional markets can cause erosion of the local knowledge of villagers on such species.

\section{ACKNOWLEDGEMENTS}

We would like to acknowledge all informants of the local traditional experts, village traders, and formal and informal leaders of Karangwangi Village, Cianjur, West Java, Indonesia who patiently and generously shared their local knowledge on traditional medicines and various aspects of the traditional village markets with the researcher. We would also like to acknowledge Rector of Padjadjaran University, Sumedang, Indonesia who financially supported this research through the program of Academic Leadership (ALG) of Prof. Johan Iskandar. 


\section{REFERENCES}

Ain AN, Sakti ERE, Syafnir L. 2016. Characterization of simplisia and mareme leaf extract (Glochidion borneense (Mull. Arg). Prosiding Farmasi 2 (2): 307-312. [Indonesian]

Albuquerque UP, Cunha LVF, Lucena REP, and Neto EMF. 2014a. Selection of Research Participants. In Albuquerque UP, Cunha LVF, Lucena RFP and Alves RRN (eds), Methods and Techniques in Ethnobiology and Ethnoecology. Springer, New York.

Albuquerque UP, Monteiro JM, Ramos MA, de Amorim ELC, Alves RRN. 2014b. Ethnobiological research in public markets. In Albuquerque UP, Cruz da Cunha LVF, Paiva de Leucena RF, Alves RRN. (eds), Methods and techniques in ethnobiology and ethnoecology. Springer Science + Business Media, New York.

Albuquerque UP, Ramos MA, de Lucena RFP, Alencar NL. 2014c. Methods and techniques used to collect ethnobiological data. In Albuquerque UP, Cruz da Cunha LVF, Paiva de Leucena RF, Alves RRN. (eds), Methods and techniques in ethnobiology and ethnoecology. Springer Science + Business Media, New York.

Alfian RL, Iskandar J, Suroso, Ermandara DP, Mulyanto D, Partasasmita R. 2020. Fish species, Traders, and Trade in Traditional Market: Case Study in Pasar Baru, Balikpapan city, East Kalimantan, Indonesia. Biodiversitas 2 (1): 393-406.

Ambaretnani P. 2012. Paraji and Bidan in Rancakekek: Integrated Medicine for Advance Partnerships among Traditional Birth Attendants and Community Midwives in the Sunda Region of West Java, Indonesia. [Thesis]. LEAD, Leiden University, Leiden.

Asmara IY, Garnida D, Sulisytati M, Tejaningsih S, Partasasmita R. 2018 Ethnoveterinary medicine and health management of Pelung Chicken in West Java, Indonesia. Biodiversitas 19: 1502-1508.

Berkes F. 2008. Sacred Ecology. $2^{\text {nd }}$ ed. Routledge, New York.

Cunningham AB. 2001. Applied ethnobotany: people, wild plant use \& conservation. Earthscan, London.

Das DR, Sachan AKR, Imtiya ZM, Shuaib M. 2015. Momordica charantia as potential medical herbs: an overview. J Med Plant Stud 3 (5): 23-26.

Dirjen POM. 1987. Indonesian Medical Materials. Indonesian Ministry of Health, Jakarta. [Indonesian]

Edwards A. 2010. Thriving beyond sustainability: Pathways to a Resilient Society. New Society Publishers, Gabriola Island.

Fadlilah A, Wijana IDP. 2018. Greeting diversity in multiethnic society in the traditional market. Daun Lontar 4 (6): 20-36.

Ferreira WS, Alencar NL, Albuquerque UP. 2014. Methods for data collection in medical ethnobiology. In Albuquerque UP, Cruz da Cunha LVF, Paiva de Leucena RF, Alves RRN. (eds), Methods and techniques in ethnobiology and ethnoecology. Springer Science + Business Media, New York.

Fitrianti T, Partasasmita R. 2020. Medicinal plants of Cintaratu Village, Pangandaran, West Java. Pros Sem Nas Masy Biodiv Indon 6: 600609 [Indonesian]

Handajani A. 2015. Utilization of medicinal plants by people around Gunung Simpang Nature Reserve, West Java. Pros Sem Nas Biodiv Indon 1 (6): 1425-1432. [Indonesia]

Hendariningrum R. 2018. Culture, and health communication (the study of health outlook on Sundanese people in the tradition of eating fresh vegetables). J Lugas 2(1): 13-19. DOI: 10.31334/jl.v2i1.118

Herliana ET. 2015. Preserving Javanese Culture through Retail Activities in Pasar Beringharjo, Yogyakarta. Procedia Soc Behav Sci 184: 206 213.

Heyne K. 1987. Useful plant in Indonesia. Badan Litbang Kehutanan, Jakarta. [Indonesian]

Idu MacD, Erhabor JO, Efijuemue HM. 2010. Documentation on medicinal plants sold in markets in Abeokuta, Nigeria. Tropical $\mathrm{J}$ Pharmaceut Res 9 (2): 110-118.

Irwanta E, Himat A, Zuhud EAM. 2015. Diversity of plant simplicial and traditional medicine product on the market in Pati Regency, Central Java. Media Konservasi 20 (3): 197-204. [Indonesian].

Iskandar J. 2007 Human ecology and sustainable development. Revision Edition. Postgraduate of Environmental Science, Padjadjaran University, Sumedang.

Iskandar J. 2018. Ethnobiology, Ethnoecology, and Sustainable Development. Graha Ilmu, Yogyakarta. [Indonesian]

Iskandar J, Iskandar BS. 2016. Ethnoecology and agroecosystem management by Karangwangi Villagers, Cidaun District, Southern Cianjur, West Java. J Biodjati 1 (1): 1-12 [Indonesian].
Iskandar BS, Iskandar J, Irawan B, Partasasmita R. 2018. Traditional markets of edible plant trading: case study in Ujung Berung, Bandung, West Java, Indonesia. Biodiversitas 19 (2): 437-452.

Iskandar BS, Iskandar J. 2020. The Role of the Village Markets to Support Community Economy and Biodiversity Conservation: A Case Study in Cidaun, Cianjur District, West Java. Padjadjaran University, Sumedang. [Indonesian]

Iskandar J, Iskandar BS, Mulyanto D, Alfian RL, Partasasmita R. 2020. Traditional ecological knowledge of the bird traders on bird species, bird naming, and bird market chain: a case study in Bird Market Pasty, Yogyakarta, Indonesia. Biodiversitas 21 (6): 2586-2

Kasahara S, Hemni S. (eds). 1995. Medical Herbal index in Indonesia. P.T. Eisai Indonesia, Jakarta.

Malini D, Madihah, Kusmoro J, Kamilawati F, Iskandar J. 2017. Ethnobotanical study of medicinal plants in Karangwangi, District of Cianjur, West Java. Biosaintifika. 9 (2): 345-356.

Martin GJ. 1996. Ethnobotany: a Methods Manual. Chapman \& Hall, London.

Maspaitella M, Garnevska E, Sidiqque MI, Shadbolt N. 2018. Toward High-Value Markets: a Case Study of Smallholder Vegetable Farmers in Indonesia. Intl Food Agribus Manag Rev 21 (1): 73-87. DOI: 10.22434/IFAMR2017.0011

Mulyanto D, Iskandar J, Abdoellah OS, Iskandar BS, Riawanti S, Partasasmita R. 2018. Leunca (Solanum americanum Mill.): the uses as vegetable in two villages in upper Citarum area, Bandung, West Java, Indonesia. Biodiversitas 19 (5): 1941-1954.

Nahraeni W, Rahayu A, Yoesdiarti A, Kulsum IA. 2018. Structure of kemangi vegetable market in traditional market. J Agribisains 4 (2): 21-29. [Indonesian]

Nastiti TS. 2003. Markets in Java in Ancient Mataram Period VIII-XI AD. PT Kiblat Buku Utama, Bandung. [Indonesian]

Nelwan JW, Lapian SLHVJ, Rumokoy FS. 2017. The Existence of traditional market toward modern market in Tomohon City. Jurnal EMBA 5 (3): 3348-3355.

Newing H, Eagle C, Puri R, Watson CW. 2011. Researching Conservation: A Social Science Perspective. Routledge, London.

Nisyapuri FF, Iskandar J, Partasasmita R. 2018. Study of ethnobotany of medicinal plants in Wonoharjo Village, Pangandaran District, West Java. Pros Sem Nas Masy Biodiv Indon 4: 122-132. [Indoensian]

Permana RCE. 2009. Baduy community and traditional medicine based on plants. Wacana 11 (1): 81-94. [Indonesian]

Partasasmita R, Iskandar J. Malone N. 2016. Karangwangi people's (Southern Cianjur, West Java, Indonesia) local knowledge of species, forest utilization and wildlife conservation. Biodiversitas 17: 154-161.

Radriamiharisoa MN, Kuhlman AR, Jeannoda V, Rabarison H, Rakotoarivelo N, Randrianarivony T, Raktoaryvony F, Randrianasolo A, Bussmann R. 2015. Medicinal Plant Sold in the markets of Antananarivo, Madagascar. J Ethnobiol Ethnomed 11 (60): 1-12. DOI: 10.1186/s 13002-015-0046-y.

Rismata N. 2012. Study on Ethnopharmacology in Citatah karst area of Gunungmasigit village, Cipatat sub-district, West Bandung. [Thesis]. Environmental Sciences Postgraduate, Padjadjaran University, Sumedang. [Indonesian].

Roosita Roosita K, Kusharto CM, Sekiyama M, Fachrurozi, Ohtsuka R. 2008. Medicinal plant used by the Villagers of Sundanese Community in West Java, Indonesia. J Ethnopharmacol 115: 72-81.

Panjaitan RGP, Mitalia, Partasasmita R. 2020. Indigenous knowledge of the people in Karya Usaha Hamlet (Kubu Raya, West Kalimantan, Indonesia) on the processing and diversity of plants that enhance toddler's appetite. Biodiversitas 21: 4284-4290

Sari ID, Yuniar Y, Siahaan S, Riswati, Syarippudin. 2015. Community tradition in planting and using medical plant in surround homegraden. J Kefarmasian Indonesia 5(2): 123-132. [Indonesian]

Septiari ED. 2016. Understanding the perception of Millinelial Generation toward Traditional Market (A Study in Yogyakarta). Rev Integr Bus Econ Res 5 (1): 30-43.

Shiva V. 2016. Who feeds the world?: the failures of agribusiness and the promise of agroecology. North Atlantic Books, Berkeley, CA.

Sidabutar AM, Arianti NN, Andani A. 2012. Income and business efficiency analysis fruits traders in Kota Bengkulu (A Case study of static and mobile traders). Agrisep 11 (2): 251-261 [Indonesian].

Siemonsma JS, Piluek P. 1994. Vegetables. PROSEA (Plant Resources of South-East Asia), Bogor.

Sihotang VBL. 2011. Ethnomedical Study of Sundanese People the Bodogol Area, Gede Pangrango Mountain National Park West Java. Gard Bull Sing 63 (1): 519-526. 
Silalahi M, Nisyawati, Waluyo EB, Supriatna J. 2015. The local knowledge of medicinal plant trader and diversity of medicinal plants in the Kabanjahe traditional market, North Sumatra, Indonesia. J Ethnopharmacol. 175: 432-443.

Soemarwoto O and Soemarwoto I. 1984. The Javanese Rural Ecosystem. In: Rambo AT, Sajise P (eds.). An Introduction to Human Ecology Research on Agricultural Systems in Southeast Asia. East-West Center, Hawaii.

Sowerwine JC. 2004. Effect of economic liberalization on Dao Women's traditional knowledge, ecology, and trade of medicinal plants in Northern Vietnam. In: Carlson TJS, Maffi L. (eds), Ethnobotany and conservation of biocultural diversity. The New York Botanical Garden Press, New York.

Statistics of Cidaun. 2017. Ciadun sub-district in Numbers 2017. BPS, Cianjur. [Indonesian]

Supangkat B. 2012. Market and Male Trader in Ujung Berung Market. [Dissertation]. Postgraduate Program of Anthropology, University of Indonesia, Depok [Indonesian].

Suryadarma D, Poesoro A, Akhmadi, Budiyati S, Rosfadhila M, Suryahadi A. 2010. Traditional food traders in developing countries and competition from supermarkets: Evidence from Indonesia. Food Pol 35: 79-86.

Suryana Y, Iskandar J. 2014. Study on local knowledge of medicinal plants in agroecosystems and dynamics of change in Cibunar Village,
Sumedang District, West Java. Bionatura 15 (3): 203-209. [Indonesian]

Susanti S, Sukaesih. 2017. Sundanese local wisdom in utilizing medicinal plants by the people of Cipatat, West Bandung District. Wacana 16 (2): 291-298. [Indonesian].

Susiarti S, Rahayu M, Rugayah. 2018. Diversity of Indonesian plant in the lowland forest, Bodogol, and its surrounding of Mount GedePangrango National Park, West Java. IOP Conf Ser Earth Environ Sci 166: 012021. DOI: 10.1088/1755-1315/166/1/012021.

Susilowati KDS. 2014. The Impacts of modern market to traditional traders (a case in Malang City-Indonesia). IJTR A 2 (8s): 38-44.

Syarifuddin D. 2018.Traditional market in tourism perspective value. J Manajemen Resort Leisure. 15 (1): 19-32 [Indonesian].

Valkenburg JLCH, Bunyapraphatsan. 1999. Prosea 12: Medical and Poisonous Plant. Prosea Foundation, Bogor.

Wicaksono MI 2016. Ethnobotanical study of the use of medicinal plants among Kawangwangi People, Cidaun Sub-district, West Java Province. [Hon. Thesis], Departement of Biology, Padjadjaran University, Sumedang. [Indonesian]

Yurlisa K, Magfhoer MD, Aini N, Sumiya W, Permanasari PN. 2017. Documentation of local vegetables in traditional market district and city of Kediri, East Java. J Biodjati 2 (1): 52-63. [Indonesian] 